\title{
Pharmacological and non-pharmacological interventions to influence adipose tissue function
}

\author{
Jan Westerink, Frank LJ Visseren ${ }^{*}$
}

\begin{abstract}
Obesity is associated with metabolic derangements such as insulin resistance, inflammation and hypercoagulobility which can all be understood as consequences of adipose tissue dysfunction. The potential role for adipose tissue derived cytokines and adipokines in the development of vascular disease and diabetes may produce a clinical need to influence adipose tissue function. Various pharmacological and non-pharmacological interventions affect plasma cytokine and adipokine levels. The effects of these interventions depend on weight loss per se, changes in fat distribution without weight loss and/or direct effects on adipose tissue inflammation.

Weight loss, as a result of diet, pharmacology and surgery, positively influences plasma adipokines and systemic inflammation. Several classes of drugs influence systemic inflammation directly through their anti-inflammatory actions. PPAR- $\gamma$ agonism positively influences adipose tissue inflammation in several classes of intervention such as the thiazolidinediones and perhaps salicylates, CB1-antagonists and angiotensin II receptor blockers. Furthermore, within drug classes there are differential effects of individual pharmacologic agents on adipose tissue function. It can be concluded that several commonly used pharmacological and non-pharmacological interventions have unintended influences on adipose tissue function. Improving adipose tissue function may contribute to reducing the risk of vascular diseases and the development of type 2 diabetes.
\end{abstract}

\section{Introduction}

The prevalence of obesity is rising worldwide [1]. As obesity is a major cause of insulin resistance, metabolic syndrome, type 2 diabetes, atherosclerosis and premature death, the incidence of these diseases is expected to rise. Imbalance between caloric intake and energy expenditure leads to hypertrophy and hyperplasia of adipose tissue [2], leading to metabolic derangements, such as dyslipidemia, elevated blood pressure, inflammation, hypercoagulobility, as a consequence of adipose tissue dysfunction [3-5].

Adipose tissue dysfunction can be viewed as a combination of pro-inflammatory changes in adipose tissue and changes in the endocrine function of adipose tissue as witnessed by changes in plasma cytokine and especially plasma adipokine levels. Visceral adipose tissue (VAT) is the predominant adipose tissue compartment responsible for the production of proinflammatory cytokines and adipokines [6].

\footnotetext{
* Correspondence: F.L.J.Visseren@umcutrecht.nl
'Department of Vascular Medicine, University Medical Center Utrecht, the

* Correspondence: F.L.J.Visseren@umcutrecht.nl
${ }^{1}$ Department of Vascular Medicine, University Medical Center Utrecht, the Netherlands
}

(c) 2011 Westerink and Visseren; licensee BioMed Central Ltd. This is an Open Access article distributed under the terms of the Creative

Various mechanisms are implicated in the initial phases of adipose tissue inflammation, most of which are a result of adipose tissue expansion [7]. The histopathology of adipose tissue inflammation in obesity is characterized by accumulation of macrophages in adipose tissue [8]. Subsequent adipose tissue inflammation leads to the systemic release of cytokines and adipokines by inflammatory cells, preadipocytes and adipocytes. Although most of the cytokines and adipokines are not solely produced by adipose tissue, they do reflect the vast production capacity of adipose tissue as exampled by the $30 \%$ contribution of adipose tissue on systemic IL-6 plasma levels [9]. As adipose tissue contributes significantly to systemic concentrations of cytokines and adipokines, plasma concentrations can therefore be regarded as a reflection of adipose tissue dysfunction.

The potential role for adipose tissue derived cytokines and adipokines in the development of vascular disease and diabetes [10-13] may produce a clinical need to influence adipose tissue function. Various pharmacological and non-pharmacological interventions, already commonly used in patients with vascular disease or type 2 diabetes affect adipose tissue function. The effects of 
these interventions may depend on weight loss but particularly on a loss of fat mass, changes in fat distribution without weight loss and/or direct effects on adipose tissue inflammation. In this paper we review the current pharmacological and non-pharmacological options and their possible underlying mechanisms for influencing adipose tissue function.

\section{Effects of weight loss on adipose tissue function}

The quantity of adipose tissue is an important driver of adipose tissue dysfunction, insulin resistance and cardiovascular disease. Therefore, to improve adipose tissue function the logical and preferred first step should be to decrease the amount of (visceral) adipose tissue. Decreasing the amount of visceral adipose tissue may be accomplished via the following mechanisms: weight loss per se, loss of fat mass with an increase in fat-free mass (such as seen with exercise) or by inducing a shift in fat distribution from visceral to subcutaneous compartments. Although not a subject of this review, altering dietary content without altering the caloric content, such as by reducing fructose intake may also have beneficial effects on adipose tissue function [10]. For example, in an isocaloric diet, fructose rather than glucose intake was associated with an increase in visceral adipose tissue in humans [14] while fructose intake in mice induces visceral and perivascular adipose tissue dysfunction $[15,16]$.

\section{Diet-induced weight loss}

Intentional weight loss is associated with lowering blood pressure in hypertensive patients, improvements in the lipid profile and a decreased incidence of diabetes [17-19]. Intentional weight loss induced by taking dietary measures improves endothelial function [20-22], lowers systemic markers of inflammation [23] and ameliorates insulin resistance [24]. In patients with and without the metabolic syndrome, $7 \%$ weight loss already reduced the prevalence of components of the metabolic syndrome such as systolic blood pressure, plasma glucose levels, triglycerides and high-density lipoprotein (HDL) cholesterol [25]. Although there are no randomized controlled trials (RCT) available showing the benefit of diet induced weight reduction on overall or cardiovascular mortality there is a clear association between obesity and mortality [26-28]. The currently ongoing Look AHEAD trial compares intensive lifestyle intervention including weight loss with diabetes support and education and has shown promising results on diabetes control and cardiovascular risk factors [18]. Influencing plasma adipokines levels such as adiponectin by a dietary intervention seems especially dependent on a reduction in fat mass [29].

Lowering the daily caloric intake by 500 kilocalories leads to a decrease in bodyweight between 5-10\% and a decrease in body mass index (BMI) by 2.0 and $2.9 \mathrm{~kg} /$ $\mathrm{m} 2$ [30-32]. This weight loss was associated with a $25 \%$ fall in leptin plasma concentrations while there was no effect on adiponectin levels [30,32]. Weight loss of 5$10 \%$ increases insulin sensitivity while marginally increasing plasma levels of adiponectin and reducing plasma levels of C-reactive protein (CRP), interleukin-6 (IL-6) and the soluble tumour necrosis factor- $\alpha$ (TNF$\alpha$ ) receptor without an effect on plasma levels of TNF$\alpha$, indicating an improvement in adipose tissue function [31,32].

If caloric intake is further restricted by $600-1000 \mathrm{kcal} /$ day, bodyweight decreases between 7 and 12\% [25,33] resulting in a $46-58 \%$ fall in plasma leptin levels and an increase of 42-65\% in adiponectin levels [25]. Apparently, diet-induced weight loss is an effective strategy for improving adipose tissue function but at least $10 \%$ weight loss is needed to improve plasma concentrations of adiponectin and inflammatory markers such as CRP. [34] Besides the amount of weight loss the duration of the weight loss period might also influence plasma adiponectin levels with adiponectin levels increasing during the weight loss maintenance period after a weight loss of $11-12 \%$ in 8 weeks [35].

\section{Medication-induced weight loss Orlistat}

Orlistat is a lipase inhibitor that decreases intestinal fat absorption after meals. Therefore, successful treatment with orlistat should be seen as a combined treatment of orlistat and a (low fat) diet. In a recent meta-analysis of 16 studies including 10,631 patients with a follow up of 1-4 years, orlistat reduced weight by $2.9 \mathrm{~kg}$ (95\% CI $2.5-$ $3.2 \mathrm{~kg}$ ) and increased absolute percentages of participants achieving $5 \%$ and $10 \%$ weight loss thresholds by $21 \%$ and $12 \%$ respectively [36]. A decrease in the incidence of type 2 diabetes mellitus from $9.0 \%$ to $6.2 \%$ (Hazard Ratio 0.63; 95\% CI 0.46-0.86) was reported. [37] Together with a dietary intervention, orlistat $(120 \mathrm{mg}$ tid.) was not associated with a change in plasma leptin and adiponectin concentrations, although resistin levels decreased by $36 \%$ after 6 months of treatment. [38] When orlistat was combined with a hypocaloric diet with a $600 \mathrm{kcal}$ restriction, bodyweight decreased by 14$24 \%$, percentage body fat by $21 \%$ and plasma concentrations of leptin, CRP, IL-6, TNF- $\alpha$, and resistin decreased while adiponectin increased, indicating an improvement in adipose tissue function [39,40].

\section{Sibutramine}

Sibutramine is a highly selective inhibitor for the reuptake of norepinefrine and serotonin at nerve endings. Originally developed as an anti-depressant, sibutramine has effects on energy intake and to a lesser extent on energy expenditure. The latter is probably mediated by brown adipose tissue thermogenesis [41]. In a meta- 
analysis of placebo-controlled randomized trials, sibutramine decreased bodyweight by $4.2 \mathrm{~kg}$ (95\% CI 3.6-4.7 kg) [36]. Compared with placebo, sibutramine however increased systolic blood pressure by $1.7 \mathrm{mmHg}$ (95\% CI $0.1-3.3)$ and pulse rate by 4.5 beats/min $(95 \%$ CI 3.5-5.6). Other common side effects included dry mouth, insomnia and nausea in $7-20 \%$.

Two small studies evaluated the combined effect of a 500-600 kcal diet restriction and sibutramine (10-15 mg daily). Bodyweight fell by only $5-7 \%$, but plasma concentrations of TNF- $\alpha$, IL- 6 , resistin, leptin and CRP levels decreased $[38,42]$. In contrast to diet only, the combination of a diet with sibutramine was associated with an increase in adiponectin and interleukin-10 (IL-10) levels while only inducing a relatively small weight loss [42]. Also, a $7 \%$ fall in bodyweight and $14 \%$ fall in fat mass due to sibutramine was associated with improved insulin resistance and a rise in adiponectin which was especially correlated with the decrease in visceral adipose tissue area [43]. The effect of sibutramine induced weight loss on adipokines seems greater than in studies in which caloric restriction is used. The question therefore arises whether sibutramine may have effects on adipose tissue function independent of sole weight loss. Catecholamine induced lipolysis has been shown to be greater in visceral adipose tissue (VAT) then in subcutaneous adipose tissue (SAT) [44]. Indeed, combining a diet with sibutramine led to a preferential loss of VAT in patients with obstructive sleep apnea [45]. This potential preferential effect on VAT may be an explanation for the greater effect of sibutramine on adipokines and cytokines than could be expected by similar weight loss with a diet alone. However, recently it has been shown that use of sibutramine is associated with an increased risk for nonfatal myocardial infarction and stroke in patients at high cardiovascular risk [46]. Since October 2010 sibutramine has therefore been withdrawn from the market.

\section{Cannabinoid-1 (CB1) receptor antagonists}

The cannabinoid-1 (CB1) receptor is widely dispersed throughout the body with high concentration in areas of the brain related to feeding [47]. CB1 receptors are also present on adipocytes [48]. The two best characterized endocannabinoids, anandamide (AEA) and 2-arachnidonylglycerol (2-AG) are both capable of activating the peroxisome proliferator-activated receptor (PPAR) $\alpha$ and $\gamma$ [49]. This activation may be induced by direct binding to PPAR or by intracellular signalling after CB receptor activation (mediated by extracellular signalregulated kinase 1/2 (ERK1/2) and p38 mitogen-acivated protein kinase (MAPK)) or by COX-2 metabolites of endocannabinoids $[49,50]$.

Interestingly enough, peripheral endocannabinoid levels are increased in human obesity, probably due to diminished insulin mediated down regulation of the endocannabinoid system in insulin resistant adipocytes $[51,52]$. The selective CB1 receptor blocker rimonabant has been investigated as a weight reduction drug in several large scale clinical trials [53-56]. Rimonabant not only has central effects on satiety but also affects the peripheral endocannabinoid system in the gut leading to nausea and diarrhoea, all of which can explain the rimonabant associated weight loss [57]. In a recent meta-analysis of placebo-controlled trials, evaluating the clinical effects of rimonabant, it appeared that the mean weight loss was $4.7 \mathrm{~kg}$ (95\% CI 4.1-5.3) more than in the placebo group [36]. Furthermore, rimonabant significantly reduced waist circumference, lowered blood pressure, lowered triglyceride levels and increased high density lipoprotein cholesterol plasma concentrations. Although rimonabant was withdrawn from the market in 2008 due to adverse effects including an increased incidence of psychiatric disorders (depression, suicidal ideation, anxiety, and aggression), other CB1 receptor antagonists are still under investigation.

In patients with type 2 diabetes, treatment with rimonabant at the highest dose $(20 \mathrm{mg})$ decreased CRP $(-26 \%)$ and leptin (-2\%)levels [55]. In overweight or obese patients with untreated dyslipidemia, rimonabant decreased leptin levels to a greater extent than in patients with diabetes (23\%) and significantly increased adiponectin levels by $37 \%$ [53]. In regression analysis $57 \%$ of the 1 -year treatment effect of rimonabant on adiponectin was thought not to be attributable to weight loss [58]. Although not completely explained, these data suggest that rimonabant may have effects on adiponectin levels beyond weight loss. Adipocytes express a CB1 receptor and may therefore be a direct target for rimonabant [48]. Also, unbound circulating endocannabinoids may still activate PPARs and may therefore provide an explanation for weight loss independent effects of rimonabant on adipose tissue function.

\section{Bariatric surgery}

Bariatric surgery is increasingly used as a strategy to reduce bodyweight and thereby ameliorate risk factors for cardiovascular disease [59-61]. On average, patients lose 14-25\% weight after bariatric surgery [62]. Patients who underwent gastric bypass surgery showed a significant decline in all-cause mortality as well as coronary artery disease, diabetes and cancer during 7.1 years follow up [26]. Patients with recently diagnosed type 2 diabetes showed greater weight loss after gastric banding compared to conventional therapy (life style advice) as well as a greater chance of remission of type 2 diabetes [63]. This effect of bariatric surgery on diabetes is probably due to a reduction in body fat mass and, in the case of gastric bypass surgery, changes in gut hormone production such as Glucagon-Like Peptide-1 (GLP-1), Gastric Inhibitory Polypeptide (GIP) and grehlin [64]. 
GLP-1 receptor agonists induce adiponectin expression while reducing expression of IL-6 and MCP-1 in 3T3-L1 adipocytes through the protein kinase A pathway [65]. Finally, although only limited data is present, plasma GIP levels may important as seen from in vitro studies showing a GIP induced reduction in insulin resistance in 3T3-L1 adipocytes through activation of Akt [66]. Although only limited data is available, the effects of GLP-1 and GIP on adipocytes may be part of the weight loss independent effects of gastric bypass surgery on adipose tissue function. Other beneficial effects of gastric bypass surgery in comparison to gastric banding may include a smaller fat mass to fat-free mass ratio with similar weight loss [67].

Adiponectin levels have been shown to increase after bariatric surgery in several small scale studies mainly because of an increase in high molecular weight adiponectin [68-70]. After bariatric surgery, plasma concentrations of Macrophage Inhibitory Factor (MIF), Plasminogen Activator Inhibitor-1 (PAI-1), Retinol Binding Protein-4 (RBP-4), Monocyte Chemotactic Protein-1 (MCP-1) and interleukin-18 (IL-18) are decreased, indicating positive effects on adipose tissue function [71-73].

\section{Effects of exercise on adipose tissue function}

The most important reason why insulin resistance increases with age is the steady increase in bodyweight and the reduction in physical activity [74]. Comparison of studies investigating the effect of exercise and diet on body weight is hampered by the different exercise schedules, combination with different dietary restrictions and different patient groups studied. Exercise does not lead to preferential loss of VAT when comparing moderate and vigorous exercise with dietary caloric restriction, nor is there a clear difference in the change of body composition [75] Both aerobic and strength exercise lead to an amelioration of insulin resistance [24]. Even short duration exercise improves insulin resistance, suggesting that some beneficial effects of exercise are not mediated by weight loss [76].

In patients with type 2 diabetes mellitus, aerobic exercise during 16 weeks was associated with a decrease in bodyweight by only 1.3 kilograms and by lower plasma concentrations of IL-6, IL-18, CRP and resistin showing an anti-inflammatory effect of exercise with only marginal weight reduction [77]. Exercise may improve adipose tissue function in healthy patients with the largest effect in the older age group as shown by an increase in plasma adiponectin levels and a decrease in plasma RBP-4 levels [78]. A recent systemic review however showed that most but not all studies investigating the effect of exercise failed to show an effect on circulating adiponectin levels probably due to the only limited weight loss associated with pure exercise studies [78,79].
These findings are compatible with data from studies investigating diet induced weight loss which showed that more than $10 \%$ weight loss is needed to elevate plasma adiponectin levels [34].

\section{Effects of pharmacologic agents on adipose tissue function \\ Salicylates}

Salicylates are among the most commonly used nonsteroidal anti-inflammatory drugs and have their main action through cyclooxygenase (COX) inhibition. Studies investigating the effects of salicylates on adipose tissue function have especially implicated specific COX-2 inhibition as the mechanism by which salicylates may improve adipose tissue function [80,81]. Besides COX inhibition, salicylates also act through inhibition of the activity of inhibitor of nuclear factor kappa-B kinase subunit beta (IKK- $\beta$ ) leading to decreased phosphorylation of inhibitor of NF- $\kappa \mathrm{B}(\mathrm{I} \kappa \mathrm{B})$ and therefore to a reduction in translocation of Nuclear Transcription factor kappa-B (NF- $\kappa \mathrm{B})$ to the nucleus [82]. Besides the direct anti-inflammatory effects, some data suggests a possible role of PPAR- $\gamma$ agonism which is of great importance in adipocyte differentiation, function and body fat composition. For example, 5-aminosalicylic acid increases PPAR-gamma expression, promotes its translocation from the cytoplasm to the nucleus, and permits the recruitment of co-activators and the activation of a peroxisome-proliferator response element-driven gene in human epithelial cells [83]

Although high dose acetylsalicylic acid (1 to 1,6 gram) has been shown to reduce fasting and post load glucose levels in patients with type 2 diabetes, the clinical use of high dose acetylsalicylic acid is limited by the increased risk of bleeding) [84]. Low dose acetylsalicylic acid (100 $\mathrm{mg}$ and $300 \mathrm{mg}$ ) had no effect on IL-6 or CRP levels in patients with type 2 diabetes during 6 weeks [85]. Salsalate at a dose of 3 grams per day however does lower fasting glucose levels and glucose levels after a oral glucose tolerance test in patients with obesity, by increasing insulin levels via an unknown mechanism [86]. In patients with type 2 diabetes, salsalate in doses of 3 and 4,5 grams per day improved insulin resistance as measured during a hyperinsulinemic euglycemic clamp, fasting and post challenge glucose levels, decreased free fatty acid (FFA) levels and increased adiponectin levels by $35-45 \%$ without an effect on bodyweight [87]. This effect of salsalate on adipose tissue dysfunction may be mediated by the before mentioned anti-inflammatory effect or by the possible PPAR- $\gamma$ agonistic action of salicylates, leading to a reduction in insulin resistance.

\section{Beta-blockers}

Although earlier reports have found a possible link between the use of beta blockers and the development 
of diabetes, some newer beta-blockers are investigated for their beneficial effects on adipose tissue dysfunction $[88,89]$. The relation between beta-blockers and diabetes can be explained by $\beta_{2}$ receptor blockade, induced reduction in thermogenesis and subsequent weight gain [90-92]. A combined $\beta 1$ and $\beta 2$-adrenoceptor agonist is capable of down regulating adiponectin and up regulating TNF- $\alpha$ mRNA in murine adipocytes [93].

Indeed, some of the newer beta blockers do have beneficial effects on insulin resistance and adipokines without changes in weight. For example nebivolol (5 mg daily), which has $\beta_{2}$ intrinsic sympaticomimetic action, increases plasma adiponectin levels in overweight patients with hypertension [94] Celiprolol (up to 400 mg daily), a combined $\beta_{1}$ antagonist and $\beta_{2}$ agonist reduces plasma leptin levels without a change in bodyweight in patients with dyslipidemia [95].

\section{Aldosterone antagonists}

Inhibition of mineralcorticosteroid receptor activation by use of aldosterone antagonists is used in the treatment of heart failure and hypertension. Besides an effect on blood pressure, spironolactone is capable of inhibiting TNF- $\alpha$, IL- 6 and Interferon- $\gamma$ (IFN- $\gamma$ ) production in isolated human mononuclear cells in vitro [96]. Far less is known about the effect of aldosterone antagonists on adipose tissue dysfunction. Adipose tissue is capable of producing an unidentified mineralcorticoid releasing factor that may stimulate aldosterone production [97]. The mineralcorticoid receptor has an important role in adipocyte differentiation as witnessed by diminished differentiation of 3T3-L1 adipocytes in the presence of dexamethason and spironolactone [98]. In obese diabetic mice, blocking the mineralcorticoid receptor reduced the expression of proinflammatory cytokines in adipose tissue while it lead to an increased expression of adiponectin in cardiac and adipose tissue [99]. Further evidence for an important role for the mineralcorticoid receptor in adipose tissue comes from a study in obese mice where blocking the mineralcorticoid receptor with eplererone ameliorated insulin resistance, decreased the number of hypertrophic adipocytes and infiltrating macrophages [100]. Furthermore, eplererone was also capable of blunting aldosterone and $\mathrm{H}_{2} \mathrm{O}_{2}$ induced radical oxygen species and dysregulated expression of obesity related genes in 3T3-L1 adipocytes. This data from in vitro and murine studies shows that aldosterone might play a relevant role in adipocyte biology. Indeed, although not a strict adipokine, plasma PAI-1 levels were reduced by spironolactone in patients with type 2 diabetes and diabetic nephropathy [101].

\section{Angiotensin Converting Enzyme Inhibitors (ACE-i)}

Angiotensin Converting Enzyme Inhibitors (ACE-i) are widely used in the treatment of heart failure and hypertension. In a large randomized trial, ramipril was associated with a lower incidence of diabetes, compared to placebo, in patients at high cardiovascular risk [102]. In patients with cardiovascular disease and impaired fasting glucose, ramipril did not reduce the incidence of diabetes mellitus but was associated with regression to normoglycaemia [103].

Circulating levels of angiotensin II are associated with changes in VAT in humans [104]. ACE-inhibitors may affect insulin resistance by reducing plasma concentrations of angiotensin II. Angiotensin II increases serine phosphorylation of the insulin receptor, insulin receptor substrate 1 and phophadidylinositol-3-kinase leading to a state of insulin resistance [105]. Angiotensin II might also influence insulin resistance via a direct pro-inflammatory effect on adipocytes and subsequent changes in MCP-1, IL-6 and IL-8 production via the NF- $\kappa$ B pathway and increased production of leptin via an ERK1/2 dependent pathway in a murine model [106-108]. Finally, ACE-i decreases total body fat mass and plasma leptin levels in a murine model [109].

Lisinopril binds to PPAR- $\gamma$, although with a low binding affinity, suggesting a possible role for a PPAR- $\gamma$ agonistic action for ACE-i [110]. ACE-i are less effective than angiotensin II type 1 receptor blockers (ARB) in raising plasma adiponectin levels [111-113], which is likely a consequence of the different effects on PPAR- $\gamma$.

\section{Angiotensin II type 1 Receptor Blockers (ARB)}

The ARB valsartan reduces the risk of developing type 2 diabetes mellitus in patients with hypertension [114]. In clinical studies it is shown that insulin resistance is indeed reduced by the use of ARBs [115,116]. Apart from blockade of the angiotensin II type 1 receptor, ARBs function as partial agonists of PPAR- $\gamma$, even in the absence of a functional AT-II receptor [117,118]. In a murine model, plasma adiponectin levels were elevated after treatment with irbesartan without a change in adiponectin mRNA levels, suggesting a post-transcriptional mechanism [119]. The effect on PPAR- $\gamma$ is further shown by studies investigating the effect of ARBs on adipose tissue distribution. Telmisartan decreases VAT by $10 \%$, as measured by $\mathrm{CT}$, without having an effect on subcutaneous fat area [120,121]. ARBs also have anti-inflammatory effects as seen by lowering effect on plasma TNF- $\alpha$ and IL- 6 levels in patients with diabetes and hypertension [120,122] Telmisartan, but not valsartan, was shown to attenuate TNF- $\alpha$ induced IL- 6 production by vascular smooth muscle cells in a PPAR- $\gamma$ dependent manner [123]. These PPAR- $\gamma$ agonistic effects of ARBs result in higher plasma levels of adiponectin [120,121,124], although no effect was observed on high-molecular weight adiponectin levels [115,116]. 


\section{Statins}

Statins might have a various direct effects on adipose tissue function by inhibiting Toll-like receptor-4 (TLR4) triggered expression of IFN- $\gamma$ in macrophages, which are abundant in adipose tissue, and through increasing PPAR- $\gamma$ expression $[125,126]$. Besides direct effects on adipose tissue, statins are also capable of reducing inflammation in general as measured by reduced plasma CRP levels [127]. Incubation of murine 3T3-L1 adipocytes with blood samples from patients treated with pravastatin induced adiponectin production [128]. However, pravastatin, a hydrophilic statin [129], did not alter insulin sensitivity, or leptin and adiponectin plasma concentrations in healthy subjects [130]. Pravastatin treatment however did elevate plasma adiponectin levels more in patients with lower baseline levels compared to patients with higher baseline adiponectin plasma concentrations $[131,132]$.

Due to differences in lipophylicity, statins may have different effects on adipose tissue function. Atorvastatin, which is more lipophylic than pravastatin [129] increases adiponectin levels in patients with coronary artery disease (CAD) or at high risk for CAD while having no effect on adiponectin in patients with diabetes [133-136]. Simvastatin, the most lipophylic statin, decreases adiponectin $[137,138]$. Rosuvastatin, a very hydrophilic statin, was able to lower visfatin levels in patients with increased risk for cardiovascular disease while simvastatin had no effect $[139,140]$. This suggests a beneficial effect of hydrophilic statins over lipophylic statins on adipose tissue dysfunction. Initially statins were thought to reduce the incidence of diabetes [141], but two recent meta analyses of statin trials on the incidence of diabetes showed that there is no or even a small increased risk of diabetes due to statin treatment without clear heterogeneity between statins [142,143].

\section{Fibrates}

Fibrates decrease the incidence of type 2 diabetes mellitus [144], by a PPAR- $\alpha$ agonistic effect [145]. The PPAR- $\alpha$ agonistic effects of fibrates also include an antiinflammatory regulatory action on macrophages by interfering with the NF- $\kappa$ B and AP-1 pathways [146]. Besides the PPAR- $\alpha$ agonistic effect, some fibrates like bezafibrate, can be seen as pan-PPAR agonists and therefore may have effects through PPAR $-\gamma$ and/or PPAR- $\beta / \delta[147,148]$ As mentioned before, this could be significant as especially PPAR- $\gamma$ is of major importance for adipocyte differentiation and function. Fibrates inhibit the expression of PAI-1 in human adipocytes and preadipocytes, an effect which is blunted when cells are co-incubated with a PPAR- $\alpha$ inhibitor [149]. In a murine model, fenofibrate increased adiponectin and visfatin mRNA levels while decreasing the expression of TNF- $\alpha$ in the VAT without an effect on serum TNF- $\alpha$ levels [150]. Short-term treatment effects of fibrates on adipose tissue function are seen by lower TNF- $\alpha$, IL-6, PAI-1, MCP-1 and RBP-4 plasma levels during treatment [151,152], and by an increase in high molecular weight adiponectin levels by $12 \%$ in patients with hypertriglyceridemia [153].

\section{Thiazolidinediones}

Peroxisome Proliferator-Activated Receptors or PPARs are ligand-activated transcription factors that belong to the nuclear receptor superfamiliy. While the thiazolidinedione (TZD) rosiglitazone is a selective PPAR- $\gamma$ agonist, pioglitazone exerts PPAR $-\gamma$ and $-\alpha$ agonistic activity which may account for the differential metabolic effects of pioglitazone and rosiglitazone. Thiazolidinediones have been investigated as potential drugs in preventing type 2 diabetes. Treatment with rosiglitazone during 3 years lowered the incidence of diabetes mellitus type 2 (HR 0.38, 95\% CI 0.33-0.44) [154].

Thiazolidinediones may directly increase insulin sensitivity in the liver and adipose tissue where it is of critical importance for adipocyte differentiation. Indeed, as a consequence of PPAR- $\gamma$ agonism, thiazolidinediones increase SAT-mass [155]. PPAR- $\gamma$ agonists are thought to promote free fatty acid uptake and storage in adipocytes and may therefore protect the liver and muscle from excess levels of free fatty acids and their toxic effects, resulting in insulin resistance. Also, PPAR- $\gamma$ agonists may have indirect effects on insulin resistance by altering adipocytokine production. Pioglitazone increases high molecular weight adiponectin and decreases TNF$\alpha$ levels and RBP-4 levels in patients with type 2 diabetes [155-157].In addition, this effect of pioglitazone on plasma levels of adiponectin is highly predictable on baseline levels [158]. Rosiglitazone increases leptin levels as would be expected due to the expansion of the SAT compartment and has effects on adipocytokine production as shown by lowering PAI-1 levels, which is partly dependent on adiponectin, and increasing adiponectin plasma levels [159-161]. Although PPAR- $\gamma$ agonists have shown considerable beneficial effects on adipose tissue function, concerns about cardiovascular safety remain. Both thiazolidinediones are associated with a $3-4 \mathrm{~kg}$ increase in bodyweight probably due to fluid retention which leads to an increased risk for heart failure $[162,163]$ Rosiglitazone therapy is associated with an increased risk for the occurrence of myocardial infarctions which has lead to the withdrawal of this drug from the market in 2010 [164]. As beneficial vascular effects are seen with pioglitazone, current research is focussing on other dual PPAR- $\alpha / \gamma$ agonists to improve not only glycemic control but also lipid levels and potentially reducing vascular risk [165]. 


\section{Metformin}

Metformin reduces the incidence of type 2 diabetes in patients with elevated fasting and post-load glucose concentrations indicating an effect of metformin in reducing insulin resistance [166]. Apart from affecting glucose uptake in the liver and in peripheral tissues, metformin has anti-inflammatory properties by inhibiting NF- $\kappa \mathrm{B}$ and blocking the PI3K-Akt pathway in human vascular wall cells [167]. Recent evidence suggests a possible role of metformin on AMP-activated protein kinase dependent lipolysis in adipocytes which may lead to lower plasma levels of fatty acids and therefore to improvement in adipose tissue function [168]. Production of PAI-1 by human subcutaneous adipose tissue (SAT) is inhibited by metformin in vitro, showing a potential direct effect of metformin on adipose tissue function [169]. However in a study with lean and obese patients with and without diabetes, metformin did not result in a reduction of BMI, nor did it affect plasma adiponectin levels after 4 months of treatment [170] Other studies have shown that metformin decreases plasma concentrations of MIF in obese patients and also decreases vaspin while increasing omentin plasma concentrations in overweight women with polycystic ovary syndrome, without an effect on bodyweight [171-173]. These results indicate a direct effect of metformin on adipose tissue in humans, beyond an effect through weight reduction. Apart from these direct effects on adipose tissue function, metformin may also work through effects on body composition. Metformin does not affect the amount of VAT, but reduces SAT, total body fat percentage, BMI and waist circumference in obese children and adolescents [174]. It can be concluded that metformin, which has an important place in the treatment of type 2 diabetes, also has direct beneficial effects on adipose tissue function.

\section{Conclusion}

Obesity related adipose tissue dysfunction may be an important risk factor for the development of vascular diseases and diabetes. Weight reduction and physical exercise improve adipose tissue function, probably to a large extent due to a reduction in fat mass. Various pharmacological agents commonly used in patients with vascular diseases or diabetes mellitus also affect adipose tissue function by various mechanisms (Table 1). Within classes

Table 1 Differential effects of currently available interventions in the treatment of adipose tissue dysfunction

\begin{tabular}{|c|c|c|}
\hline Intervention & $\begin{array}{l}\text { Mechanism of action responsible for the effect on } \\
\text { cytokines and adipokines }\end{array}$ & Effect on cytokines and adipokines \\
\hline Diet & Weight loss & Adiponectin $\uparrow$, leptin $\downarrow, I L-6 \downarrow$, sTNF- $\alpha$ receptor type $1 \downarrow$ \\
\hline Orlistat & Weight loss & Adiponectin $\uparrow$, resistin $\downarrow$, leptin $\downarrow, \mid L-6 \downarrow, T N F-\alpha \downarrow$ \\
\hline Sibutramine & Weight loss & Adiponectin $\uparrow$, resistin $\downarrow$, leptin $\downarrow, \mid L-10 \uparrow, T N F-\alpha \downarrow, I L-6 \downarrow$ \\
\hline \multirow[t]{2}{*}{ CB1-antagonists } & Weight loss & Adiponectin $\uparrow$, leptin $\downarrow$ \\
\hline & Effects through PPAR $\gamma$ activation & \\
\hline \multirow[t]{2}{*}{ Bariatric surgery } & Weight loss & $\begin{array}{l}\text { Adiponectin } \uparrow, \text { HMW adiponectin } \uparrow, \text { RBP- } 4 \downarrow, \text { PAI- } 1 \downarrow \text {, } \\
\text { MIF } \downarrow, \text { MCP-1 } \downarrow, I L-18 \downarrow\end{array}$ \\
\hline & Effects on gut hormones & \\
\hline Exercise & Weight loss & Adiponectin $\uparrow$, resistin $\downarrow$, RBP-4 $4, I L-6 \downarrow, I L-18 \downarrow$ \\
\hline \multirow[t]{2}{*}{ Salicylates } & Anti-inflammatory & Adiponectin $\uparrow$ \\
\hline & COX-2 inhibition & \\
\hline$\beta$-blocker & $\beta_{2}$ adrenoreceptor activation & Adiponectin $\uparrow$, leptin $\downarrow$ \\
\hline Aldosteron antagonists & Aldosteron antagonism & PAl-1 $\downarrow$ \\
\hline $\begin{array}{l}\text { Angiotensin Converting } \\
\text { Enzyme inhibitors }\end{array}$ & Inhibition of the renin-angiotensin system & Adiponectin $\uparrow$ \\
\hline \multirow{2}{*}{$\begin{array}{l}\text { Angiotensin II type } 1 \text { receptor } \\
\text { blockers }\end{array}$} & Inhibition of the renin-angiotensin system & Adiponectin $\uparrow, T N F-\alpha \downarrow, I L-6 \downarrow$ \\
\hline & Effects through PPAR $\gamma$ activation & \\
\hline $\begin{array}{l}(\mathrm{HMG}-\mathrm{Co} A) \text { reductase } \\
\text { inhibitors }\end{array}$ & Anti-inflammatory & Adiponectin $\uparrow \downarrow$, visfatin $\downarrow$ \\
\hline \multirow[t]{2}{*}{ Fibrates } & Effects through PPAR $\alpha$ activation & Adiponectin $\uparrow, \mathrm{RBP}-4 \downarrow, \mathrm{PAI}-1 \downarrow, \mathrm{MCP}-1 \downarrow, \mathrm{TNF}-\alpha \downarrow, \mid L-6 \downarrow$ \\
\hline & Effects through PPAR $\gamma$ activation & \\
\hline \multirow[t]{2}{*}{ Metformin } & Anti-inflammatory & Vaspin $\downarrow$, MIF $\downarrow$ \\
\hline & AMPK activation & \\
\hline Thiazolidinediones & Effects through PPAR $\gamma$ activation & $\begin{array}{l}\text { Adiponectin } \uparrow, \text { HMW adiponectin } \uparrow, \text { leptin } \uparrow, ~ R B P-4 \downarrow \text {, } \\
\text { PAI- } 1 \downarrow\end{array}$ \\
\hline
\end{tabular}

AMPK: AMP activated protein kinase, CB-1 antagonists: Cannabinoid-1 antagonist, IL: Interleukin, MCP-1: Monocyte chemoattractant protein-1, MIF: Macrophage Inhibitory Factor, PAI-1: Plasminogen activator inhibitor-1, PPAR: Peroxisome Proliferator Activated Receptors, RBP-4: Retinol Binding Protein 4, TNF- $\alpha$ : Tumor Necrosis Factor- $\alpha$. 
of drugs there are differential effects of individual pharmacological agents. Although the effects of these drugs on adipose tissue function are unintended, improving adipose tissue function may contribute to reducing the risk of vascular diseases and the development of type 2 diabetes. However, the clinical relevance of influencing adipose tissue function remains to be determined.

\section{Abbreviations}

2-AG: 2-Arachnidonyl Glycerol; ACE: Angiotensin Converting Enzyme; AEA Anandamide; ARB: Angiotensin II type 1 receptor blocker; AT-II: Angiotensin II; BMI: Body Mass Index; CAD: Coronary Artery Disease; CB-1: Cannabinoid-1; COX: Cyclooxygenase; CRP: C-Reactive Protein; ERK1/2: Extracellular signalRegulated Kinas 1/2; FFA: Free Fatty Acids; GIP: Gastric Inhibitory Polypeptide; GLP-1:Glucagon-Like Peptide 1; HDL; High Density Lipoprotein IFN-ץ: Interferon-ү; IL: Interleukin; MAPK: Mitogen-Activated Protein Kinase; MCP-1: Monocyte Chemoattractant Protein 1; MIF: Macrophage Inhibitory Factor; PAl-1: Plasminogen Activator Inhibitor 1; PPAR: Peroxisome Proliferator-Activated Receptor; RBP-4: Retinol Binding Protein 4; SAT: Subcutaneous Adipose Tissue; TLR-4: Toll-Like Receptor 4; TNF-a: Tumour Necrosis Factor-a; TZD: Thiazolidinediones; VAT: Visceral Adipose Tissue;

\section{Acknowledgements}

This work was supported by a grant from the Leatare Foundation, Monaco and the Catharijne Foundation, the Netherlands.

\section{Authors' contributions}

JW has designed the review, acquired the data and drafted the manuscript FLJV has been involved in revising the article critically for important intellectual content and gave final approval of the version to be published. Both authors have read and approved the final manuscript.

\section{Competing interests}

The authors declare that they have no competing interests.

Received: 3 January 2011 Accepted: 28 January 2011

Published: 28 January 2011

\section{References}

1. Ogden CL, Yanovski SZ, Carroll MD, Flegal KM: The epidemiology of obesity. Gastroenterology 2007, 132:2087-2102.

2. Drolet R, Richard C, Sniderman AD, Mailloux J, Fortier M, Huot C, et al: Hypertrophy and hyperplasia of abdominal adipose tissues in women. Int J Obes (Lond) 2007.

3. Mokdad AH, Ford ES, Bowman BA, Dietz WH, Vinicor F, Bales VS, et al: Prevalence of obesity, diabetes, and obesity-related health risk factors, 2001. JAMA 2003, 289:76-79.

4. Yusuf S, Hawken S, Ounpuu S, Bautista L, Franzosi MG, Commerford P, et al: Obesity and the risk of myocardial infarction in 27,000 participants from 52 countries: a case-control study. Lancet 2005, 366:1640-1649.

5. Hajer GR, van Haeften TW, Visseren FL: Adipose tissue dysfunction in obesity, diabetes, and vascular diseases. Eur Heart J 2008, 29:2959-2971.

6. Fain JN, Madan AK, Hiler ML, Cheema P, Bahouth SW: Comparison of the release of adipokines by adipose tissue, adipose tissue matrix, and adipocytes from visceral and subcutaneous abdominal adipose tissues of obese humans. Endocrinology 2004, 145:2273-2282.

7. Hotamisligil GS: Inflammation and metabolic disorders. Nature 2006, 444:860-867.

8. Weisberg SP, McCann D, Desai M, Rosenbaum M, Leibel RL, Ferrante AW Jr: Obesity is associated with macrophage accumulation in adipose tissue. J Clin Invest 2003, 112:1796-1808.

9. Mohamed-Ali V, Goodrick S, Rawesh A, Katz DR, Miles JM, Yudkin JS, et al: Subcutaneous adipose tissue releases interleukin-6, but not tumor necrosis factor-alpha, in vivo. J Clin Endocrinol Metab 1997, 82:4196-4200.

10. Dekker JM, Funahashi T, Nijpels G, Pilz S, Stehouwer CD, Snijder MB, et al: Prognostic value of adiponectin for cardiovascular disease and mortality. J Clin Endocrinol Metab 2008, 93:1489-1496.
11. Graham TE, Yang Q, Bluher M, Hammarstedt A, Ciaraldi TP, Henry RR, et al Retinol-binding protein 4 and insulin resistance in lean, obese, and diabetic subjects. N Engl J Med 2006, 354:2552-2563.

12. Hajer GR, van der Graaf $Y$, Olijhoek JK, Edlinger M, Visseren FL: Low plasma levels of adiponectin are associated with low risk for future cardiovascular events in patients with clinical evident vascular disease. Am Heart J 2007, 154:750-757.

13. Piemonti L, Calori G, Lattuada G, Mercalli A, Ragogna F, Garancini MP, et al: Association between plasma monocyte chemoattractant protein-1 concentration and CVD mortality in middle-aged diabetic and nondiabetic individuals. Diabetes Care 2009, 32:2105-2110.

14. Stanhope KL, Schwarz JM, Keim NL, Griffen SC, Bremer AA, Graham JL, et al: Consuming fructose-sweetened, not glucose-sweetened, beverages increases visceral adiposity and lipids and decreases insulin sensitivity in overweight/obese humans. J Clin Invest 2009, 119:1322-1334.

15. Alzamendi A, Giovambattista A, Raschia A, Madrid V, Gaillard RC, Rebolledo O, et al: Fructose-rich diet-induced abdominal adipose tissue endocrine dysfunction in normal male rats. Endocrine 2009, 35:227-232.

16. Rebolledo A, Rebolledo OR, Marra CA, Garcia ME, Roldan Palomo AR, Rimorini $L$, et al: Early alterations in vascular contractility associated to changes in fatty acid composition and oxidative stress markers in perivascular adipose tissue. Cardiovasc Diabetol 2010, 9:65.

17. Knowler WC, Barrett-Connor E, Fowler SE, Hamman RF, Lachin JM, Walker $E A$, et al: Reduction in the incidence of type 2 diabetes with lifestyle intervention or metformin. N Engl J Med 2002, 346:393-403.

18. Pi-Sunyer X, Blackburn G, Brancati FL, Bray GA, Bright R, Clark JM, et al: Reduction in weight and cardiovascular disease risk factors in individuals with type 2 diabetes: one-year results of the look AHEAD trial. Diabetes Care 2007, 30:1374-1383.

19. Stevens VJ, Corrigan SA, Obarzanek E, Bernauer E, Cook NR, Hebert P, et al: Weight loss intervention in phase 1 of the Trials of Hypertension Prevention. The TOHP Collaborative Research Group. Arch Intern Med 1993, 153:849-858

20. Clifton PM, Keogh JB, Foster PR, Noakes M: Effect of weight loss on inflammatory and endothelial markers and FMD using two low-fat diets. Int J Obes (Lond) 2005, 29:1445-1451.

21. Hamdy O, Ledbury S, Mullooly C, Jarema C, Porter S, Ovalle K, et al: Lifestyle modification improves endothelial function in obese subjects with the insulin resistance syndrome. Diabetes Care 2003, 26:2119-2125.

22. Keogh JB, Brinkworth GD, Clifton PM: Effects of weight loss on a lowcarbohydrate diet on flow-mediated dilatation, adhesion molecules and adiponectin. Br J Nutr 2007, 98:852-859.

23. Bougoulia M, Triantos A, Koliakos G: Plasma interleukin-6 levels, glutathione peroxidase and isoprostane in obese women before and after weight loss. Association with cardiovascular risk factors. Hormones (Athens) 2006, 5:192-199.

24. Weinstock RS, Dai H, Wadden TA: Diet and exercise in the treatment of obesity: effects of 3 interventions on insulin resistance. Arch Intern Med 1998, 158:2477-2483.

25. Xydakis AM, Case CC, Jones PH, Hoogeveen RC, Liu MY, Smith EO, et al: Adiponectin, inflammation, and the expression of the metabolic syndrome in obese individuals: the impact of rapid weight loss through caloric restriction. J Clin Endocrinol Metab 2004, 89:2697-2703.

26. Adams TD, Gress RE, Smith SC, Halverson RC, Simper SC, Rosamond WD, et al: Long-term mortality after gastric bypass surgery. N Engl J Med 2007, 357:753-761.

27. Flegal KM, Graubard BI, Williamson DF, Gail MH: Cause-specific excess deaths associated with underweight, overweight, and obesity. JAMA 2007, 298:2028-2037.

28. Williamson DF, Thompson TJ, Thun M, Flanders D, Pamuk E, Byers T: Intentional weight loss and mortality among overweight individuals with diabetes. Diabetes Care 2000, 23:1499-1504.

29. Rokling-Andersen MH, Reseland JE, Veierod MB, Anderssen SA, Jacobs DR Jr, Urdal P, et al: Effects of long-term exercise and diet intervention on plasma adipokine concentrations. Am J Clin Nutr 2007, 86:1293-1301.

30. Miller GD, Nicklas BJ, Davis CC, Ambrosius WT, Loeser RF, Messier SP: Is serum leptin related to physical function and is it modifiable through weight loss and exercise in older adults with knee osteoarthritis? Int J Obes Relat Metab Disord 2004, 28:1383-1390.

31. Nicklas BJ, Ambrosius W, Messier SP, Miller GD, Penninx BW, Loeser RF, et al: Diet-induced weight loss, exercise, and chronic inflammation in older, 
obese adults: a randomized controlled clinical trial. Am J Clin Nutr 2004, 79:544-551.

32. Weiss EP, Racette SB, Villareal DT, Fontana L, Steger-May K, Schechtman KB, et al: Improvements in glucose tolerance and insulin action induced by increasing energy expenditure or decreasing energy intake: a randomized controlled trial. Am J Clin Nutr 2006, 84:1033-1042.

33. Hotta K, Funahashi T, Arita Y, Takahashi M, Matsuda M, Okamoto Y, et al: Plasma concentrations of a novel, adipose-specific protein, adiponectin, in type 2 diabetic patients. Arterioscler Thromb Vasc Biol 2000, 20:1595-1599.

34. Madsen EL, Rissanen A, Bruun JM, Skogstrand K, Tonstad S, Hougaard DM, et al: Weight loss larger than $10 \%$ is needed for general improvement of levels of circulating adiponectin and markers of inflammation in obese subjects: a 3-year weight loss study. Eur J Endocrinol 2008, 158:179-187.

35. Christiansen T, Paulsen SK, Bruun JM, Ploug T, Pedersen SB, Richelsen B: Diet-induced weight loss and exercise alone and in combination enhance the expression of adiponectin receptors in adipose tissue and skeletal muscle, but only diet-induced weight loss enhanced circulating adiponectin. J Clin Endocrinol Metab 2010, 95:911-919.

36. Rucker D, Padwal R, Li SK, Curioni C, Lau DC: Long term pharmacotherapy for obesity and overweight: updated meta-analysis. BMJ 2007, 335:1194-1199.

37. Torgerson JS, Hauptman J, Boldrin MN, Sjostrom L: XENical in the prevention of diabetes in obese subjects (XENDOS) study: a randomized study of orlistat as an adjunct to lifestyle changes for the prevention of type 2 diabetes in obese patients. Diabetes Care 2004, 27:155-161.

38. Valsamakis G, McTernan PG, Chetty R, Al DN, Field A, Hanif W, et al: Modest weight loss and reduction in waist circumference after medical treatment are associated with favorable changes in serum adipocytokines. Metabolism 2004, 53:430-434.

39. Bougoulia M, Triantos A, Koliakos G: Effect of weight loss with or without orlistat treatment on adipocytokines, inflammation, and oxidative markers in obese women. Hormones (Athens) 2006, 5:259-269.

40. Hsieh CJ, Wang PW, Liu RT, Tung SC, Chien WY, Chen JF, et al: Orlistat for obesity: benefits beyond weight loss. Diabetes Res Clin Pract 2005, 67:78-83.

41. Lean ME: How does sibutramine work? Int J Obes Relat Metab Disord 2001, 25(Suppl 4):S8-11.

42. Jung SH, Park HS, Kim KS, Choi WH, Ahn CW, Kim BT, et al: Effect of weight loss on some serum cytokines in human obesity: increase in IL-10 after weight loss. J Nutr Biochem 2008, 6:371-375.

43. Kim DM, Yoon SJ, Ahn CW, Cha BS, Lim SK, Kim KR, et al: Sibutramine improves fat distribution and insulin resistance, and increases serum adiponectin levels in Korean obese nondiabetic premenopausal women. Diabetes Res Clin Pract 2004, 66(Suppl 1):S139-S144.

44. Ramis JM, Salinas R, Garcia-Sanz JM, Moreiro J, Proenza AM, Llado I: Depotand gender-related differences in the lipolytic pathway of adipose tissue from severely obese patients. Cell Physiol Biochem 2006, 17:173-180.

45. Phillips CL, Yee BJ, Trenell MI, Magnussen JS, Wang D, Banerjee D, et al: Changes in regional adiposity and cardio-metabolic function following a weight loss program with sibutramine in obese men with obstructive sleep apnea. J Clin Sleep Med 2009, 5:416-421.

46. James WP, Caterson ID, Coutinho W, Finer N, Van Gaal LF, Maggioni AP, et al: Effect of sibutramine on cardiovascular outcomes in overweight and obese subjects. N Engl J Med 2010, 363:905-917.

47. Demuth DG, Molleman A: Cannabinoid signalling. Life Sci 2006, 78:549-563.

48. Howlett AC, Barth F, Bonner TI, Cabral G, Casellas P, Devane WA, et al: International Union of Pharmacology. XXVII. Classification of cannabinoid receptors. Pharmacol Rev 2002, 54:161-202.

49. Sun Y, Bennett A: Cannabinoids: A New Group of Agonists of PPARs. PPAR Res 2007, 2007:23513.

50. O'Sullivan SE: Cannabinoids go nuclear: evidence for activation of peroxisome proliferator-activated receptors. Br J Pharmacol 2007, 152:576-582.

51. Engeli S, Bohnke J, Feldpausch M, Gorzelniak K, Janke J, Batkai S, et al: Activation of the peripheral endocannabinoid system in human obesity. Diabetes 2005, 54:2838-2843.

52. D'Eon TM, Pierce KA, Roix JJ, Tyler A, Chen H, Teixeira SR: The role of adipocyte insulin resistance in the pathogenesis of obesity-related elevations in endocannabinoids. Diabetes 2008

53. Despres JP, Golay A, Sjostrom L: Effects of rimonabant on metabolic risk factors in overweight patients with dyslipidemia. N Engl J Med 2005, 353:2121-2134.
54. Pi-Sunyer FX, Aronne LJ, Heshmati HM, Devin J, Rosenstock J: Effect of rimonabant, a cannabinoid-1 receptor blocker, on weight and cardiometabolic risk factors in overweight or obese patients: RIO-North America: a randomized controlled trial. JAMA 2006, 295:761-775.

55. Scheen AJ, Finer N, Hollander P, Jensen MD, Van Gaal LF: Efficacy and tolerability of rimonabant in overweight or obese patients with type 2 diabetes: a randomised controlled study. Lancet 2006, 368:1660-1672.

56. Van Gaal LF, Rissanen AM, Scheen AJ, Ziegler O, Rossner S: Effects of the cannabinoid-1 receptor blocker rimonabant on weight reduction and cardiovascular risk factors in overweight patients: 1-year experience from the RIO-Europe study. Lancet 2005, 365:1389-1397.

57. Izzo AA, Camilleri M: Emerging role of cannabinoids in gastrointestina and liver diseases: basic and clinical aspects. Gut 2008, 57:1140-1155.

58. Van GL, Pi-Sunyer X, Despres JP, McCarthy C, Scheen A: Efficacy and safety of rimonabant for improvement of multiple cardiometabolic risk factors in overweight/obese patients: pooled 1-year data from the Rimonabant in Obesity (RIO) program. Diabetes Care 2008, 31(Suppl 2):S229-S240.

59. Demaria EJ: Bariatric surgery for morbid obesity. N Engl J Med 2007, 356:2176-2183

60. Flum DR, Belle SH, King WC, Wahed AS, Berk P, Chapman W, et al: Perioperative safety in the longitudinal assessment of bariatric surgery. N Engl I Med 2009, 361:445-454.

61. Sjostrom L, Lindroos AK, Peltonen M, Torgerson J, Bouchard C, Carlsson B, et al: Lifestyle, diabetes, and cardiovascular risk factors 10 years after bariatric surgery. N Engl J Med 2004, 351:2683-2693.

62. Sjostrom L, Narbro K, Sjostrom CD, Karason K, Larsson B, Wedel H, et al: Effects of bariatric surgery on mortality in Swedish obese subjects. $N$ Engl J Med 2007, 357:741-752.

63. Dixon JB, O'Brien PE, Playfair J, Chapman L, Schachter LM, Skinner S, et al: Adjustable gastric banding and conventional therapy for type 2 diabetes: a randomized controlled trial. JAMA 2008, 299:316-323.

64. Vetter ML, Cardillo S, Rickels MR, lqbal N: Narrative review: effect of bariatric surgery on type 2 diabetes mellitus. Ann Intern Med 2009, 150:94-103.

65. Kim Chung IT, Hosaka T, Yoshida M, Harada N, Sakaue H, Sakai T, et al: Exendin-4, a GLP-1 receptor agonist, directly induces adiponectin expression through protein kinase A pathway and prevents inflammatory adipokine expression. Biochem Biophys Res Commun 2009, 390:613-618

66. Song DH, Getty-Kaushik L, Tseng E, Simon J, Corkey BE, Wolfe MM: Glucose-dependent insulinotropic polypeptide enhances adipocyte development and glucose uptake in part through Akt activation. Gastroenterology 2007, 133:1796-1805.

67. Lubrano C, Mariani S, Badiali M, Cuzzolaro M, Barbaro G, Migliaccio S, et al: Metabolic or bariatric surgery? Long-term effects of malabsorptive vs restrictive bariatric techniques on body composition and cardiometabolic risk factors. Int J Obes (Lond) 2010, 34:1404-1414.

68. Diker D, Vishne T, Maayan R, Weizman A, Vardi P, Dreznik Z, et al: Impact of gastric banding on plasma adiponectin levels. Obes Surg 2006, 16:1057-1061.

69. Gomez-Ambrosi J, Salvador J, Rotellar F, Silva C, Catalan V, Rodriguez A, et al: Increased serum amyloid A concentrations in morbid obesity decrease after gastric bypass. Obes Surg 2006, 16:262-269.

70. Haider DG, Schindler K, Schaller G, Prager G, Wolzt M, Ludvik B: Increased plasma visfatin concentrations in morbidly obese subjects are reduced after gastric banding. J Clin Endocrinol Metab 2006, 91:1578-1581.

71. Haider DG, Schindler K, Prager G, Bohdjalian A, Luger A, Wolzt M, et al: Serum retinol-binding protein 4 is reduced after weight loss in morbidly obese subjects. J Clin Endocrinol Metab 2007, 92:1168-1171.

72. Schernthaner GH, Kopp HP, Kriwanek S, Krzyzanowska K, Satler M, Koppensteiner $\mathrm{R}$, et al: Effect of massive weight loss induced by bariatric surgery on serum levels of interleukin-18 and monocytechemoattractant-protein-1 in morbid obesity. Obes Surg 2006, 16:709-715.

73. van Dielen FM, Buurman WA, Hadfoune M, Nijhuis J, Greve JW: Macrophage inhibitory factor, plasminogen activator inhibitor-1, other acute phase proteins, and inflammatory mediators normalize as a result of weight loss in morbidly obese subjects treated with gastric restrictive surgery. J Clin Endocrinol Metab 2004, 89:4062-4068.

74. Amati F, Dube JJ, Coen PM, Stefanovic-Racic M, Toledo FG, Goodpaster BH: Physical inactivity and obesity underlie the insulin resistance of aging. Diabetes Care 2009, 32:1547-1549. 
75. Nicklas BJ, Wang X, You T, Lyles MF, Demons J, Easter L, et al: Effect of exercise intensity on abdominal fat loss during calorie restriction in overweight and obese postmenopausal women: a randomized, controlled trial. Am J Clin Nutr 2009, 89:1043-1052.

76. Sari R, Balci MK, Balci N, Karayalcin U: Acute effect of exercise on plasma leptin level and insulin resistance in obese women with stable caloric intake. Endocr Res 2007, 32:9-17.

77. Kadoglou NP, lliadis F, Angelopoulou N, Perrea D, Ampatzidis G, Liapis CD, et al: The anti-inflammatory effects of exercise training in patients with type 2 diabetes mellitus. Eur J Cardiovasc Prev Rehabil 2007, 14:837-843.

78. Lim S, Choi SH, Jeong IK, Kim JH, Moon MK, Park KS, et al: Insulinsensitizing effects of exercise on adiponectin and retinol-binding protein-4 concentrations in young and middle-aged women. J Clin Endocrinol Metab 2008, 93:2263-2268.

79. Simpson KA, Singh MA: Effects of exercise on adiponectin: a systematic review. Obesity (Silver Spring) 2008, 16:241-256

80. Hsieh PS, Jin JS, Chiang CF, Chan PC, Chen CH, Shih KC: COX-2-mediated inflammation in fat is crucial for obesity-linked insulin resistance and fatty liver. Obesity (Silver Spring) 2009, 17:1150-1157.

81. Hsieh PS, Lu KC, Chiang CF, Chen CH: Suppressive effect of COX2 inhibitor on the progression of adipose inflammation in high-fatinduced obese rats. Eur J Clin Invest 2010, 40:164-171.

82. Yin MJ, Yamamoto Y, Gaynor RB: The anti-inflammatory agents aspirin and salicylate inhibit the activity of I(kappa)B kinase-beta. Nature 1998, 396:77-80

83. Rousseaux C, Lefebvre B, Dubuquoy L, Lefebvre P, Romano O, Auwerx J, et al: Intestinal antiinflammatory effect of 5-aminosalicylic acid is dependent on peroxisome proliferator-activated receptor-gamma. J Exp Med 2005, 201:1205-1215.

84. Reid J, Macdougall Al, Andrews MM: Aspirin and diabetes mellitus. Br Med J 1957, 2:1071-1074.

85. Hovens MM, Snoep JD, Groeneveld Y, Frolich M, Tamsma JT, Huisman MV: Effects of aspirin on serum C-reactive protein and interleukin- 6 levels in patients with type 2 diabetes without cardiovascular disease: a randomized placebo-controlled crossover trial. Diabetes Obes Metab 2008, 8:668-674

86. Koska J, Ortega E, Bunt JC, Gasser A, Impson J, Hanson RL, et al: The effect of salsalate on insulin action and glucose tolerance in obese nondiabetic patients: results of a randomised double-blind placebocontrolled study. Diabetologia 2009, 52:385-393.

87. Goldfine AB, Silver R, Aldhahi W, Cai D, Tatro E, Lee J, et al: Use of Salsalate to Target Inflammation in the Treatment of Insulin Resistance and Type 2 Diabetes. Clin Trans/ Sci 2008, 1:36-43.

88. Gress TW, Nieto FJ, Shahar E, Wofford MR, Brancati FL: Hypertension and antihypertensive therapy as risk factors for type 2 diabetes mellitus. Atherosclerosis Risk in Communities Study. N Engl J Med 2000, 342:905-912.

89. Pollare $T$, Lithell $H$, Selinus I, Berne C: Sensitivity to insulin during treatment with atenolol and metoprolol: a randomised, double blind study of effects on carbohydrate and lipoprotein metabolism in hypertensive patients. BMJ 1989, 298:1152-1157.

90. Cruickshank JM: Are we misunderstanding beta-blockers. Int J Cardio/ 2007, 120:10-27.

91. Sawicki PT, Siebenhofer A: Betablocker treatment in diabetes mellitus. J Intern Med 2001, 250:11-17.

92. Sharma AM, Pischon T, Hardt S, Kunz I, Luft FC: Hypothesis: Betaadrenergic receptor blockers and weight gain: A systematic analysis. Hypertension 2001, 37:250-254.

93. Fasshauer M, Klein J, Neumann S, Eszlinger M, Paschke R: Adiponectin gene expression is inhibited by beta-adrenergic stimulation via protein kinase A in 3T3-L1 adipocytes. FEBS Lett 2001, 507:142-146.

94. Celik T, Iyisoy A, Kursaklioglu H, Kardesoglu E, Kilic S, Turhan H, et al: Comparative effects of nebivolol and metoprolol on oxidative stress, insulin resistance, plasma adiponectin and soluble P-selectin levels in hypertensive patients. J Hypertens 2006, 24:591-596.

95. Malminiemi K: Long-term celiprolol therapy lowers fasting plasma leptin levels. Celiprolol Multicenter Study Group. Cardiovasc Drugs Ther 2000, 14:67-75.

96. Hansen PR, Rieneck K, Bendtzen K: Spironolactone inhibits production of proinflammatory cytokines by human mononuclear cells. Immunol Lett 2004, 91:87-91.
97. Lamounier-Zepter V, Ehrhart-Bornstein M: Fat tissue metabolism and adrenal steroid secretion. Curr Hypertens Rep 2006, 8:30-34

98. Caprio M, Feve B, Claes A, Viengchareun S, Lombes M, Zennaro MC: Pivotal role of the mineralocorticoid receptor in corticosteroid-induced adipogenesis. FASEB J 2007, 21:2185-2194

99. Guo C, Ricchiuti V, Lian BQ, Yao TM, Coutinho P, Romero JR, et al: Mineralocorticoid receptor blockade reverses obesity-related changes in expression of adiponectin, peroxisome proliferator-activated receptorgamma, and proinflammatory adipokines. Circulation 2008, 117:2253-2261.

100. Hirata A, Maeda N, Hiuge A, Hibuse T, Fujita K, Okada T, et al: Blockade of mineralocorticoid receptor reverses adipocyte dysfunction and insulin resistance in obese mice. Cardiovasc Res 2009, 84:164-172.

101. Matsumoto S, Takebayashi K, Aso Y: The effect of spironolactone on circulating adipocytokines in patients with type 2 diabetes mellitus complicated by diabetic nephropathy. Metabolism 2006, 55:1645-1652.

102. Yusuf S, Sleight P, Pogue J, Bosch J, Davies R, Dagenais G: Effects of an angiotensin-converting-enzyme inhibitor, ramipril, on cardiovascular events in high-risk patients. The Heart Outcomes Prevention Evaluation Study Investigators. N Engl J Med 2000, 342:145-153.

103. Yusuf S, Gerstein H, Hoogwerf B, Pogue J, Bosch J, Wolffenbuttel BH, et al: Ramipril and the development of diabetes. JAMA 2001, 286:1882-1885.

104. Saiki A, Ohira M, Endo K, Koide N, Oyama T, Murano T, et al: Circulating angiotensin II is associated with body fat accumulation and insulin resistance in obese subjects with type 2 diabetes mellitus. Metabolism 2009, 58:708-713.

105. Folli F, Kahn CR, Hansen H, Bouchie JL, Feener EP: Angiotensin II inhibits insulin signaling in aortic smooth muscle cells at multiple levels. A potential role for serine phosphorylation in insulin/angiotensin II crosstalk. J Clin Invest 1997, 100:2158-2169.

106. Skurk T, van $H$ V, Hauner $H$ : Angiotensin II stimulates the release of interleukin- 6 and interleukin-8 from cultured human adipocytes by activation of NF-kappaB. Arterioscler Thromb Vasc Biol 2004, 24:1199-1203.

107. Skurk T, van $H$ V, Blum WF, Hauner $H$ : Angiotensin II promotes leptin production in cultured human fat cells by an ERK1/2-dependent pathway. Obes Res 2005, 13:969-973.

108. Tsuchiya $K$, Yoshimoto $T$, Hirono $Y$, Tateno $T$, Sugiyama T, Hirata $Y$ : Angiotensin II induces monocyte chemoattractant protein-1 expression via a nuclear factor-kappaB-dependent pathway in rat preadipocytes. Am J Physiol Endocrinol Metab 2006, 291:E771-E778

109. Mathai ML, Naik S, Sinclair AJ, Weisinger HS, Weisinger RS: Selective reduction in body fat mass and plasma leptin induced by angiotensinconverting enzyme inhibition in rats. Int J Obes (Lond) 2008, 32:1576-1584

110. Storka A, Vojtassakova E, Mueller M, Kapiotis S, Haider DG, Jungbauer A et al: Angiotensin inhibition stimulates PPARgamma and the release of visfatin. Eur J Clin Invest 2008, 38:820-826.

111. Delles C, Raff U, Mimran A, Fauvel JP, Ruilope LM, Schmieder RE: Effects of telmisartan and ramipril on adiponectin and blood pressure in patients with type 2 diabetes. Am J Hypertens 2008, 21:1330-1336.

112. Nakamura T, Kawachi K, Saito Y, Saito T, Morishita K, Hoshino J, et al: Effects of ARB or ACE-inhibitor administration on plasma levels of aldosterone and adiponectin in hypertension. Int Heart J 2009, 50:501-512.

113. Yilmaz Ml, Sonmez A, Caglar K, Celik T, Yenicesu M, Eyileten T, et al: Effect of antihypertensive agents on plasma adiponectin levels in hypertensive patients with metabolic syndrome. Nephrology (Carlton) 2007, 12:147-153.

114. Kjeldsen SE, Julius S, Mancia G, Mclnnes GT, Hua T, Weber MA, et al: Effects of valsartan compared to amlodipine on preventing type 2 diabetes in highrisk hypertensive patients: the VALUE trial. J Hypertens 2006, 24:1405-1412.

115. Benndorf RA, Rudolph T, Appel D, Schwedhelm E, Maas R, Schulze F, et al: Telmisartan improves insulin sensitivity in nondiabetic patients with essential hypertension. Metabolism 2006, 55:1159-1164.

116. Usui I, Fujisaka S, Yamazaki K, Takano A, Murakami S, Yamazaki Y, et al: Telmisartan reduced blood pressure and HOMA-IR with increasing plasma leptin level in hypertensive and type 2 diabetic patients. Diabetes Res Clin Pract 2007, 77:210-214.

117. Janke J, Schupp M, Engeli S, Gorzelniak K, Boschmann M, Sauma L, et al: Angiotensin type 1 receptor antagonists induce human in-vitro adipogenesis through peroxisome proliferator-activated receptorgamma activation. J Hypertens 2006, 24:1809-1816.

118. Schupp M, Janke J, Clasen R, Unger T, Kintscher U: Angiotensin type 1 receptor blockers induce peroxisome proliferator-activated receptorgamma activity. Circulation 2004, 109:2054-2057. 
119. Clasen R, Schupp M, Foryst-Ludwig A, Sprang C, Clemenz M, Krikov M, et al: PPARgamma-activating angiotensin type-1 receptor blockers induce adiponectin. Hypertension 2005, 46:137-143.

120. Chujo D, Yagi K, Asano A, Muramoto H, Sakai S, Ohnishi A, et al: Telmisartan treatment decreases visceral fat accumulation and improves serum levels of adiponectin and vascular inflammation markers in Japanese hypertensive patients. Hypertens Res 2007, 30:1205-1210.

121. Shimabukuro M, Tanaka H, Shimabukuro T: Effects of telmisartan on fat distribution in individuals with the metabolic syndrome. J Hypertens 2007, 25:841-848.

122. Derosa G, Cicero AF, D'Angelo A, Ragonesi PD, Ciccarelli L, Piccinni MN, et al: Telmisartan and irbesartan therapy in type 2 diabetic patients treated with rosiglitazone: effects on insulin-resistance, leptin and tumor necrosis factor-alpha. Hypertens Res 2006, 29:849-856.

123. Tian Q, Miyazaki R, Ichiki T, Imayama I, Inanaga $K$, Ohtsubo H, et al: Inhibition of tumor necrosis factor-alpha-induced interleukin-6 expression by telmisartan through cross-talk of peroxisome proliferatoractivated receptor-gamma with nuclear factor kappaB and CCAAT/ enhancer-binding protein-beta. Hypertension 2009, 53:798-804.

124. Furuhashi M, Ura N, Higashiura K, Murakami H, Tanaka M, Moniwa N, et al: Blockade of the renin-angiotensin system increases adiponectin concentrations in patients with essential hypertension. Hypertension 2003, 42:76-81.

125. Abe M, Matsuda M, Kobayashi H, Miyata Y, Nakayama Y, Komuro R, et al: Effects of statins on adipose tissue inflammation: their inhibitory effect on MyD88-independent IRF3/IFN-beta pathway in macrophages. Arterioscler Thromb Vasc Biol 2008, 28:871-877.

126. Desjardins F, Sekkali B, Verreth W, Pelat M, De KD, Mertens A, et al: Rosuvastatin increases vascular endothelial PPARgamma expression and corrects blood pressure variability in obese dyslipidaemic mice. Eur Heart J 2008, 29:128-137.

127. Ridker PM, Danielson E, Fonseca FA, Genest J, Gotto AM Jr, Kastelein JJ, et al: Rosuvastatin to prevent vascular events in men and women with elevated C-reactive protein. N Engl J Med 2008, 359:2195-2207.

128. Takagi T, Matsuda M, Abe M, Kobayashi H, Fukuhara A, Komuro R, et al: Effect of pravastatin on the development of diabetes and adiponectin production. Atherosclerosis 2008, 196:114-121.

129. Shitara Y, Sugiyama Y: Pharmacokinetic and pharmacodynamic alterations of 3-hydroxy-3-methylglutaryl coenzyme A (HMG-CoA) reductase inhibitors: drug-drug interactions and interindividual differences in transporter and metabolic enzyme functions. Pharmacol Ther 2006, 112:71-105.

130. Gannage-Yared MH, Azar RR, mm-Azar M, Khalife S, Germanos-Haddad M, Neemtallah R, et al: Pravastatin does not affect insulin sensitivity and adipocytokines levels in healthy nondiabetic patients. Metabolism 2005, 54:947-951.

131. Sakamoto K, Sakamoto T, Ogawa H: The effect of 6 months of treatment with pravastatin on serum adiponection concentrations in Japanese patients with coronary artery disease and hypercholesterolemia: a pilot study. Clin Ther 2006, 28:1012-1021.

132. Sugiyama S, Fukushima H, Kugiyama K, Maruyoshi H, Kojima S, Funahashi T, et al: Pravastatin improved glucose metabolism associated with increasing plasma adiponectin in patients with impaired glucose tolerance and coronary artery disease. Atherosclerosis 2007, 194:e43-e51.

133. Blanco-Colio LM, Martin-Ventura JL, Gomez-Guerrero C, Masramon X, de TE, Farsang $C$, et al: Adiponectin plasma levels are increased by atorvastatin treatment in subjects at high cardiovascular risk. Eur J Pharmacol 2008, 586:259-265.

134. Ichida Y, Hasegawa G, Fukui M, Obayashi H, Ohta M, Fujinami A, et al: Effect of atorvastatin on in vitro expression of resistin in adipocytes and monocytes/macrophages and effect of atorvastatin treatment on serum resistin levels in patients with type 2 diabetes. Pharmacology 2006, 76:34-39.

135. Miyagishima K, Hiramitsu S, Kato S, Kato Y, Kitagawa F, Teradaira R, et al: Efficacy of atorvastatin therapy in ischaemic heart disease - effects on oxidized low-density lipoprotein and adiponectin. J Int Med Res 2007, 35:534-539.

136. Otto C, Otto B, Frost RJ, Vogeser M, Pfeiffer AF, Spranger J, et al: Short-term therapy with atorvastatin or fenofibrate does not affect plasma ghrelin, resistin or adiponectin levels in type 2 diabetic patients with mixed hyperlipoproteinaemia. Acta Diabetol 2007, 44:65-68.
137. Devaraj S, Siegel D, Jialal I: Simvastatin ( $40 \mathrm{mg} /$ day), adiponectin levels, and insulin sensitivity in subjects with the metabolic syndrome. Am J Cardiol 2007, 100:1397-1399.

138. Forst T, Pfutzner A, Lubben G, Weber M, Marx N, Karagiannis E, et al: Effect of simvastatin and/or pioglitazone on insulin resistance, insulin secretion, adiponectin, and proinsulin levels in nondiabetic patients at cardiovascular risk-the PIOSTAT Study. Metabolism 2007, 56:491-496.

139. Pfutzner A, Hanefeld M, Lubben G, Weber MM, Karagiannis E, Kohler C, et al: Visfatin: a putative biomarker for metabolic syndrome is not influenced by pioglitazone or simvastatin treatment in nondiabetic patients at cardiovascular risk - results from the PIOSTAT study. Horm Metab Res 2007, 39:764-768.

140. Kostapanos MS, Derdemezis CS, Filippatos TD, Milionis HJ, Kiortsis DN, Tselepis $A D$, et al: Effect of rosuvastatin treatment on plasma visfatin levels in patients with primary hyperlipidemia. Eur J Pharmacol 2008, 578:249-252.

141. Freeman DJ, Norrie J, Sattar N, Neely RD, Cobbe SM, Ford I, et al: Pravastatin and the development of diabetes mellitus: evidence for a protective treatment effect in the West of Scotland Coronary Prevention Study. Circulation 2001, 103:357-362.

142. Rajpathak SN, Kumbhani DJ, Crandall J, Barzilai N, Alderman M, Ridker PM: Statin therapy and risk of developing type 2 diabetes: a meta-analysis. Diabetes Care 2009, 32:1924-1929.

143. Sattar N, Preiss D, Murray HM, Welsh P, Buckley BM, de Craen AJ, et al: Statins and risk of incident diabetes: a collaborative meta-analysis of randomised statin trials. Lancet 2010, 375:735-742.

144. Tenenbaum A, Motro M, Fisman EZ, Adler Y, Shemesh J, Tanne D, et al: Effect of bezafibrate on incidence of type 2 diabetes mellitus in obese patients. Eur Heart J 2005, 26:2032-2038.

145. Hiuge A, Tenenbaum A, Maeda N, Benderly M, Kumada M, Fisman EZ, et al: Effects of peroxisome proliferator-activated receptor ligands, bezafibrate and fenofibrate, on adiponectin level. Arterioscler Thromb Vasc Biol 2007, 27:635-641.

146. Rigamonti E, Chinetti-Gbaguidi G, Staels B: Regulation of macrophage functions by PPAR-alpha, PPAR-gamma, and LXRs in mice and men. Arterioscler Thromb Vasc Biol 2008, 28:1050-1059.

147. Tenenbaum A, Motro M, Fisman EZ: Dual and pan-peroxisome proliferator-activated receptors (PPAR) co-agonism: the bezafibrate lessons. Cardiovasc Diabetol 2005, 4:14.

148. Krey G, Braissant O, L'Horset F, Kalkhoven E, Perroud M, Parker MG, et al: Fatty acids, eicosanoids, and hypolipidemic agents identified as ligands of peroxisome proliferator-activated receptors by coactivator-dependent receptor ligand assay. Mol Endocrinol 1997, 11:779-791.

149. Zirlik A, Ernst S, Leugers A, Willecke F, Sobel BE, Bode C, et al: Inhibition by fibrates of plasminogen activator inhibitor type- 1 expression in human adipocytes and preadipocytes. Thromb Haemost 2009, 101:1060-1069.

150. Choi KC, Ryu OH, Lee KW, Kim HY, Seo JA, Kim SG, et al: Effect of PPARalpha and -gamma agonist on the expression of visfatin, adiponectin, and TNF-alpha in visceral fat of OLETF rats. Biochem Biophys Res Commun 2005, 336:747-753.

151. Okopien B, Krysiak R, Herman ZS: Effects of short-term fenofibrate treatment on circulating markers of inflammation and hemostasis in patients with impaired glucose tolerance. J Clin Endocrinol Metab 2006, 91:1770-1778.

152. Wu H, Wei L, Bao Y, Lu J, Huang P, Liu Y, et al: Fenofibrate reduces serum retinol-binding protein-4 by suppressing its expression in adipose tissue. Am J Physiol Endocrinol Metab 2009, 296:E628-E634.

153. Oki K, Koide J, Nakanishi S, Nakashima R, Yamane K: Fenofibrate increases high molecular weight adiponectin in subjects with hypertriglyceridemia. Endocr J 2007, 54:431-435.

154. Gerstein HC, Yusuf S, Bosch J, Pogue J, Sheridan P, Dinccag N, et al: Effect of rosiglitazone on the frequency of diabetes in patients with impaired glucose tolerance or impaired fasting glucose: a randomised controlled trial. Lancet 2006, 368:1096-1105.

155. Miyazaki Y, Mahankali A, Matsuda M, Mahankali S, Hardies J, Cusi K, et al: Effect of pioglitazone on abdominal fat distribution and insulin sensitivity in type 2 diabetic patients. J Clin Endocrinol Metab 2002, 87:2784-2791.

156. Aso Y, Yamamoto R, Suetsugu M, Matsumoto S, Wakabayashi S, Matsutomo R, et al: Comparison of the effects of pioglitazone and voglibose on circulating total and high-molecular-weight adiponectin, 
and on two fibrinolysis inhibitors, in patients with Type 2 diabetes. Diabet Med 2007, 24:962-968.

157. Lin KD, Chang YH, Wang CL, Yang YH, Hsiao PJ, Li TH, et al: Thiazolidinedione addition reduces the serum retinol-binding protein 4 in type 2 diabetic patients treated with metformin and sulfonylurea. Transl Res 2008, 151:309-314.

158. Ikeda Y, Osaki F, Maruyama H, Inada S, Shinahara M, Inoue K, et al: The Effect of pioglitazone on circulating adiponectin is highly predictable based on its basal level. Diabetes Res Clin Pract 2008, 80:e12-e13.

159. Kim HJ, Kim SK, Shim WS, Lee JH, Hur KY, Kang ES, et al: Rosiglitazone improves insulin sensitivity with increased serum leptin levels in patients with type 2 diabetes mellitus. Diabetes Res Clin Pract 2008, 81:42-49.

160. van H V, Reynisdottir S, Eriksson P, Thorne A, Hoffstedt J, Lonnqvist F, et al Leptin secretion from subcutaneous and visceral adipose tissue in women. Diabetes 1998, 47:913-917.

161. Hoo RL, Chow WS, Yau MH, Xu A, Tso AW, Tse HF, et al: Adiponectin mediates the suppressive effect of rosiglitazone on plasminogen activator inhibitor-1 production. Arterioscler Thromb Vasc Biol 2007, 27:2777-2782

162. Erdmann E, Dormandy JA, Charbonnel B, Massi-Benedetti M, Moules IK, Skene AM: The effect of pioglitazone on recurrent myocardial infarction in 2,445 patients with type 2 diabetes and previous myocardial infarction: results from the PROactive (PROactive 05) Study. J Am Coll Cardiol 2007, 49:1772-1780

163. Home PD, Pocock SJ, Beck-Nielsen H, Curtis PS, Gomis R, Hanefeld M, et al: Rosiglitazone evaluated for cardiovascular outcomes in oral agent combination therapy for type 2 diabetes (RECORD): a multicentre, randomised, open-label trial. Lancet 2009, 373:2125-2135.

164. Nissen SE, Wolski K: Rosiglitazone Revisited: An Updated Meta-analysis of Risk for Myocardial Infarction and Cardiovascular Mortality. Arch Intern Med 2010, 14:170.

165. Henry RR, Lincoff AM, Mudaliar S, Rabbia M, Chognot C, Herz M: Effect of the dual peroxisome proliferator-activated receptor-alpha/gamma agonist aleglitazar on risk of cardiovascular disease in patients with type 2 diabetes (SYNCHRONY): a phase II, randomised, dose-ranging study. Lancet 2009, 374:126-135.

166. Knowler WC, Barrett-Connor E, Fowler SE, Hamman RF, Lachin JM, Walker $E A$, et al: Reduction in the incidence of type 2 diabetes with lifestyle intervention or metformin. N Engl J Med 2002, 346:393-403.

167. Isoda K, Young JL, Zirlik A, MacFarlane LA, Tsuboi N, Gerdes N, et al: Metformin inhibits proinflammatory responses and nuclear factorkappaB in human vascular wall cells. Arterioscler Thromb Vasc Biol 2006, 26:611-617.

168. Bourron O, Daval M, Hainault I, Hajduch E, Servant JM, Gautier JF, et al: Biguanides and thiazolidinediones inhibit stimulated lipolysis in human adipocytes through activation of AMP-activated protein kinase. Diabetologia 2010, 53:768-778.

169. He G, Pedersen SB, Bruun JM, Lihn AS, Richelsen B: Metformin, but not thiazolidinediones, inhibits plasminogen activator inhibitor-1 production in human adipose tissue in vitro. Horm Metab Res 2003, 35:18-23.

170. Phillips SA, Ciaraldi TP, Kong AP, Bandukwala R, Aroda V, Carter L, et al: Modulation of circulating and adipose tissue adiponectin levels by antidiabetic therapy. Diabetes 2003, 52:667-674.

171. Dandona P, Aljada A, Ghanim H, Mohanty P, Tripathy C, Hofmeyer D, et al: Increased plasma concentration of macrophage migration inhibitory factor (MIF) and MIF mRNA in mononuclear cells in the obese and the suppressive action of metformin. J Clin Endocrinol Metab 2004, 89:5043-5047.

172. Tan BK, Heutling D, Chen J, Farhatullah S, Adya R, Keay SD, et al: Metformin decreases the adipokine vaspin in overweight women with polycystic ovary syndrome concomitant with improvement in insulin sensitivity and a decrease in insulin resistance. Diabetes 2008, 57:1501-1507.

173. Tan BK, Adya R, Farhatullah S, Chen J, Lehnert H, Randeva HS: Metformin Treatment May Increase Omentin-1 Levels in Women with Polycystic Ovary Syndrome. Diabetes 2010.
174. Srinivasan S, Ambler GR, Baur LA, Garnett SP, Tepsa M, Yap F, et al: Randomized, controlled trial of metformin for obesity and insulin resistance in children and adolescents: improvement in body composition and fasting insulin. J Clin Endocrinol Metab 2006, 91:2074-2080.

doi:10.1186/1475-2840-10-13

Cite this article as: Westerink and Visseren: Pharmacological and nonpharmacological interventions to influence adipose tissue function. Cardiovascular Diabetology 2011 10:13.

\section{Submit your next manuscript to BioMed Central and take full advantage of:}

- Convenient online submission

- Thorough peer review

- No space constraints or color figure charges

- Immediate publication on acceptance

- Inclusion in PubMed, CAS, Scopus and Google Scholar

- Research which is freely available for redistribution

Submit your manuscript at www.biomedcentral.com/submit
Ciomed Central 